Article

\title{
Purple Sulfur Bacteria Dominate Microbial Community in Brazilian Limestone Cave
}

\author{
Eric L. S. Marques ${ }^{1, *(1)}$, João C. T. Dias ${ }^{1}$, Eduardo Gross ${ }^{2}{ }^{(\mathbb{D}}$, Adriana B. de Cerqueira e Silva ${ }^{1}$, \\ Suzana R. de Moura ${ }^{1}$ and Rachel P. Rezende ${ }^{1, *(D)}$ \\ 1 Department of Biological Sciences, State University of Santa Cruz, Rod. Jorge Amado, Km 16, Ilheus CEP: \\ 45662-900, Bahia, Brazil; jctdias@gmail.com (J.C.T.D.); adrianabarros_ufba@hotmail.com (A.B.d.C.eS.); \\ suzana.moura@yahoo.com.br (S.R.d.M.) \\ 2 Department of Agricultural and Environmental Science, State University of Santa Cruz, Rod. Jorge Amado, \\ Km 16, Ilheus CEP: 45662-900, Bahia, Brazil; egross@uesc.br \\ * Correspondence: marques.ericls@gmail.com (E.L.S.M.); rezende.rachel@gmail.com (R.P.R.); \\ Tel.: +55-73-3680-5435 (E.L.S.M.); +55-73-3680-5441 (R.P.R.)
}

Received: 30 November 2018; Accepted: 13 January 2019; Published: 23 January 2019

check for updates

\begin{abstract}
The mineralogical composition of caves makes the environment ideal for inhabitation by microbes. However, the bacterial diversity in the cave ecosystem remains largely unexplored. In this paper, we described the bacterial community in an oxic chamber of the Sopradeira cave, an iron-rich limestone cave, in the semiarid region of Northeast Brazil. The microbial population in the cave samples was studied by $16 \mathrm{~S}$ rDNA next-generation sequencing. A type of purple sulfur bacteria (PSB), Chromatiales, was found to be the most abundant in the sediment (57\%), gravel-like (73\%), and rock samples (96\%). The predominant PSB detected were Ectothiorhodospiraceae, Chromatiaceae, and Woeseiaceae. We identified the PSB in a permanently aphotic zone, with no sulfur detected by energy-dispersive X-ray (EDX) spectroscopy. The absence of light prompted us to investigate for possible nitrogen fixing (nifH) and ammonia oxidizing (amoA) genes in the microbial samples. The nifH gene was found to be present in higher copy numbers than the bacterial-amo $A$ and archaeal-amo $A$ genes, and archaeal-amo $A$ dominated the ammonia-oxidizing community. Although PSB dominated the bacterial community in the samples and may be related to both nitrogen-fixing and ammonia oxidizing bacteria, nitrogen-fixing associated gene was the most detected in those samples, especially in the rock. The present work demonstrates that this cave is an interesting hotspot for the study of ammonia-oxidizing archaea and aphotic PSB.
\end{abstract}

Keywords: Chromatiales; amoA; nifH; AOA; AOB; qPCR; Illumina; 16S rDNA

\section{Introduction}

Caves offer a unique environment for microbial life, which is an aphotic, non-photosynthetic, and commonly oligotrophic environment, isolated to some degree from the surface. They present a distinct mineralogical composition, associated with rocks [1-3] that provide an opportunity for colonization by different microbial communities. Recently, there was an increase in the number of studies conducted on microbial communities in tropical caves, especially those close to the Equator line (such as Brazilian caves) [4-8]. However, these caves represent only a small fraction of the many existing tropical caves, and most of these studies are based on cultured fungi and bacteria [5,7]. Additionally, culture-based studies do not reveal complete information regarding the microbial diversity of a region. On the contrary, culture-independent techniques not only provide more detailed information regarding the microbial communities inhabiting the caves, but also reveal the various diverse and unexpected [6] metabolic activities that exist within the cave ecosystem $[4,9,10]$. 
Among the unexpected microbes found in caves are the Chromatiales, also known as purple sulfur bacteria (PSB), described in microbiology books as phototrophic anoxygenic bacteria that use hydrogen sulfide as an electron donor [11]. However, PSB, such as the ones belonging to the genus Halothiobacillus, grow in aphotic and aerobic conditions [12]. Despite their photosynthetic and sulfur metabolizing ability, PSB are commonly found associated with nitrogen fixation [13] and ammonia oxidation [14], carbon fixation and chemolithoautotrophy [15], and potentially perform these activities in the cave ecosystem. Previous studies showed PSB to be the dominant bacteria in photic zones of caves [16] and nondominant members of the microbial community in the aphotic zones, such as the yellow microbial community [17].

In this study, we focused on the bacterial community in Sopradeira cave, a limestone cave in the semiarid Northeast region of Brazil. There are few microbiological studies based in caves in the NE region of Brazil $[4,5,18,19]$, which comprise an area of 1.55 million $\mathrm{km}^{2}$. Additionally, most of these studies were conducted by our group $[4,18,19]$. Among the 200 known caves of the karstic area of Sopradeira cave, only one microbiological study was conducted, which was a culture-based study on cellulolytic fungi in Gruta do Catão [5]. Therefore, the microbial diversity within these caves remains largely unexplored. The Sopradeira cave is at least $4 \mathrm{~km}$ long and is not open for tourism. It is located in the Neoproterozoic metamorphic limestones, outcropping from arenitic deposits. The cave's rock presented a reddish color, uncommon in the area, and was found to be an iron-rich limestone cave. Therefore, we decided to analyze the microbial community in two types of samples (sediment and rock) by next-generation sequencing of $16 \mathrm{~S}$ rDNA. We initially aimed to compare the composition of the bacterial community in oxic sediment and rock samples of Sopradeira cave. However, the predominant presence of Chromatiales in the aphotic environment led us to evaluate the hypothesis that these bacteria are associated with the nitrogen cycle, especially nitrogen fixation and ammonia oxidation.

\section{Materials and Methods}

\subsection{Sampling and DNA Extraction}

We collected approximately $100 \mathrm{~g}$ of sediment and gravel-like samples and a piece of approximately $100 \mathrm{~g}$ of rock sample from the same chamber of a cave called Buraco da Sopradeira (Sopradeira cave, $12^{\circ} 26^{\prime} 55^{\prime \prime} \mathrm{S} 44^{\circ} 57^{\prime} 56^{\prime \prime} \mathrm{W}$ ) located in São Desidério, Bahia state, Brazil. The amount and number of samples were authorized by SISBIO/IBAMA/MMA No. 38453 and limited for protection of the site. The cave was selected based on its reddish color and size, which were essential factors for selection, among the 200 known caves in the area. The vertical projection of the cave and abyss makes this cave exclusively accessible to the scientific and speleological communities and the absence of visible drippings makes this cave a sparsely external-contaminated site. Therefore, the cave is suitable for analysis of the microbial community. We collected a composite sample of five subsamples of sediment and gravel-like samples (Figure $\mathrm{S} 1$ shows examples of sediment and gravel-like samples) $2 \mathrm{~m}$ away from each other in a $10 \mathrm{~m}^{2}$ area of the chamber. Sediment and gravel-like samples were collected from the surface to a depth of $2 \mathrm{~cm}$ (maximum depth of sediments). A rock sample was collected at a height of $1 \mathrm{~m}$ from the cave floor, located approximately $1 \mathrm{~km}$ from the entrance and stored in sterile plastic bags and kept on ice, until reaching the laboratory. DNA extraction was carried out using the MoBio PowerSoil DNA isolation kit (MoBio Laboratories, Carlsbad, CA, USA), following the manufacturer's instructions. The rock sample was crushed using sterile mortar and pestles, prior to extraction. DNA extraction and preparation for the procedure, were performed in a laminar flow hood.

\subsection{EDX, $p H$, Organic Matter, and Nitrogen Analysis}

An EDX analysis was performed by scanning electron microscopy (model Quanta 250 (FEI Company). Stubs were used to mount each sample separately and three points were analyzed at $15 \mathrm{kV}$. Spectrographs are shown in Figure S2. At the laboratory, a part of the gravel-like and rock samples was crushed. Thereafter we sieved these and the sediment samples individually through a $2 \mathrm{~mm}$ mesh. 
Samples were sent to a service provider at the Soil Department of the Federal University of Viçosa for nitrogen analysis. Furthermore, analysis of organic matter, nitrogen, nitrate, and ammonia were performed following procedures developed by the service provider [20]. Measurement of $\mathrm{pH}$ was done following the protocol of Ribeiro et al. [20]. Samples were kept frozen until analysis.

\section{3. $16 \mathrm{~S}$ rDNA Sequencing}

Amplification of the 16S rRNA V3/V4 region was carried out using the 341F (5'- CCT ACG GGR SGC AGC AG) and 806R (5'- GGA CTA CHV GGG TWT CTA AT-3') primers [21,22]. The 16S rRNA libraries were constructed following PCR-based protocol [23] and sequenced using the MiSeq Sequencing System (Illumina Inc., San Diego, CA, USA) with the V2 kit, 300 Cycles. Reads were separated by barcoding and trimmed using Geneious 11.0.4. Chimeras were detected using decipher [24]. Operational taxonomic units (OTUs) were assigned by clustering the sequence against RDP database (version 2.12, https://rdp.cme.msu.edu/) [25] and EZBioCloud database (version 2017.05, https:/ /www.ezbiocloud.net/) [26] using a cutoff of $97 \%$, followed by the calculation of Shannon index and Good's coverage index.

\subsection{Quantitative PCR}

Quantitative PCR (qPCR) was performed on the ABI prism 7500 fast system (Applied Biosystems, Foster City, CA, USA) to quantify nifH, archaeal amoA, and bacterial amoA genes in the samples. Amplification was performed with 1X of Kapa Sybr Fast qPCR master mix with ROX (Kapa Biosystems, Wilmington, MA, USA), $0.2 \mu \mathrm{M}$ of each primer, and $2 \mu \mathrm{L}$ of extracted DNA in a final volume of $20 \mu \mathrm{L}$. A standard curve was plotted with 10-fold dilutions of a cloned PCR product for each gene analyzed. All analyses were performed in triplicate. The amplification of nifH, archaeal amoA, and bacterial amoA genes were performed using the following primers: PolF (5'-TGC GAY CCS AAR GCB GAC TC-3') and PolR (5'-ATS GCC ATC ATY TCR CCG GA-3') for nifH [27]; Arch-amoAF (5'-STA ATG GTC TGG CTT AGA CG-3') and Arch-amoAR (5'-GCG GCC ATC CAT CTG TAT GT-3') for archaeal amoA [27]; and amoA1F (5'-GGG GTT TCT ACT GGT GGT-3'); and amoA2R (5'-CCC CTC KGS AAA GCC TTC TTC-3') for bacterial amoA [27].

\section{Results}

\subsection{5 rDNA Sequencing}

The $16 \mathrm{~S}$ rDNA sequencing on Illumina platform resulted in at least 86,000 reads per sample. After processing, a minimum of 69,000 high-quality reads were obtained (Table 1). The gravel-like sample presented the highest numbers of OTU and highest diversity according to the Shannon index (Table 1). The rock sample presented the lowest number of OTU and an intermediate diversity. However, the Good's coverage indicates that the rock sample is close to a complete estimate sampling of species/OTU in comparison with the other samples (Table 1). Similar results were found in rarefaction curves (Figure S3).

Table 1. Summary of $16 \mathrm{~S}$ rDNA sequencing and analysis of Sopradeira cave samples. R (rock), G (gravel-like), and S (sediment).

\begin{tabular}{cccccc}
\hline Samples & Raw Reads & Reads after Processing & OTU & Shannon & Good's Coverage (\%) \\
\hline $\mathbf{R}$ & 86,230 & 69,751 & 2640 & 5.3 & 99.94 \\
G & 176,263 & 91,131 & 3802 & 5.7 & 99.86 \\
S & 125,347 & 72,822 & 2667 & 4.7 & 99.89 \\
\hline
\end{tabular}

We detected a total of 17 phyla in the samples. Proteobacteria predominated in all samples with $57 \%, 73 \%$, and $96 \%$ in samples S (sediment), G (Gravel-like), and R (rock), respectively, followed by Firmicutes $(34 \%, 20 \%$ and $0.6 \%$ ) and other phyla (Figure 1A). The predominant class in S, G, and 
R samples were Gammaproteobacteria (47\%, 66\%, and 93\%, respectively), Deltaproteobacteria (5\%, $2 \%$, and $1 \%$, respectively), Alphaproteobacteria $(4 \%, 4 \%$, and $2 \%$, respectively) from the phylum Proteobacteria, and Bacilli (32\%, 19\%, and 0.3\%, respectively) from the phylum Firmicutes (Figure 1B). Gammaproteobacterial order, Chromatiales, predominated in all three samples, S, G, and R with 47, 62 , and $88 \%$, respectively (Figure 1C), followed by Bacillales (30\%, 19\%, and $0.18 \%$ in samples S, G, and $\mathrm{R}$, respectively). In the family analysis, we identified three families among the Chormotiales order: Ectothiorhodospiraceae, Chromatiaceae, and Woeseiaceae. However, Bacillaceae represented a major part of the microbial community in the $S$ and $G$ samples (Figure 1D). Ectothiorhodospiraceae was the most abundant family found in these samples, while in the rock sample, Chromatiaceae and Woeseiaceae presented a similar representation (Figure 1D).
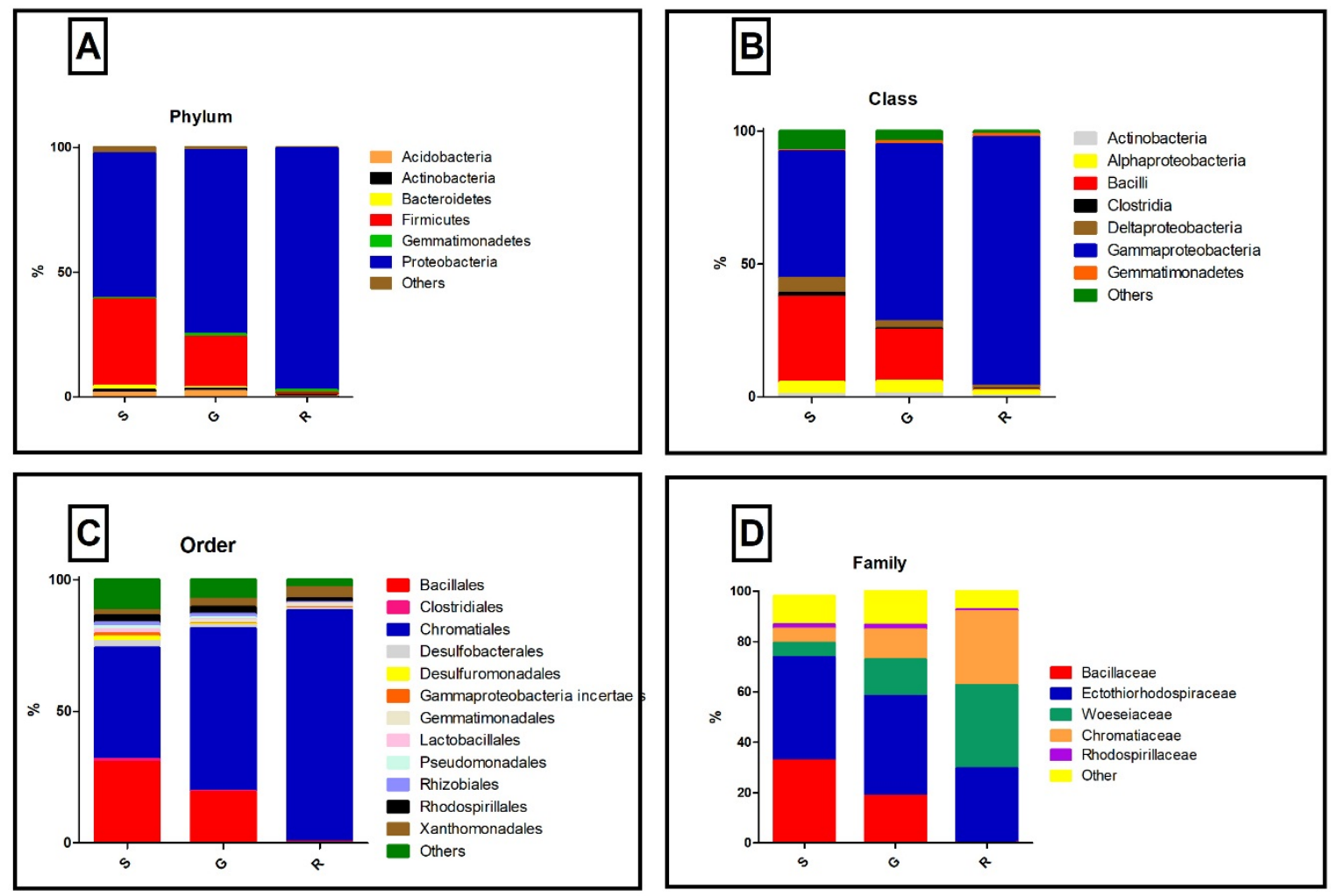

Figure 1. Taxonomic classification of $16 \mathrm{~S}$ rDNA reads for the cave samples. Sediment (S), Gravel-like (G), and Rock (R) samples. (A) Phylum level, (B) Class level, (C) Order level, and (D) Family level with EzBiocloud database.

We attempted to classify the microbial population up to the genus level by comparing our results with information available on two databases. However, the dominant genus remained unclassified, and were represented as 'family_uc' (for example, Chromatiaceae_uc), or the level of confidence for a specific genus was too low, including a small difference among the purple sulfur bacteria family's distribution. The unclassified genera represented $80 \%$ of the rock sample and at least $50 \%$ of the other samples (Table S1).

It is noteworthy that concordance between results was observed when bacterial sequences were compared with both databases independently. Therefore, sequence comparison with each database resulted in identification of the same taxa, enabling accurate classification of these bacteria up to family and genus level. However, in RDP database version 2.12, we were unable to detect Woeseiaceae, as this newly described family was not present in the database. The genus Nitrococcus, a nitrifying Ectothiorhodospiraceae, was detected in rock, sediment, and gravel-like samples at $8.8 \%, 4.1 \%$, and $6.6 \%$, respectively. Moreover, Bacillus represented 35\% (S), 19\% (G), and 0.08\% (R) of the bacterial 
community in those samples. Steroidobacter, a Gammaproteobacteria, was also found to be present in the samples, especially rock (1.5\%).

The dominance of PSB in the absence of light and sulfur led us to analyze another important metabolic function of this group: Nitrogen metabolism. However, most of the dominant species were assigned with low confidence level and associated with nitrogen metabolism, such as Nitrosococcus as the dominant Chromatiales. This encouraged us to analyze nitrogen fixation and ammonia oxidation in the samples. Furthermore, a nifH-DGGE analysis (Figure S4) showed the presence of OTUs associated with two PSB: Ectothiorhodospirceae and Chromatiaceae (Text S1).

\subsection{Quantitative PCR ( $q P C R)$}

The frequency of nifH was found to be higher than bacterial-amoA by at least 100-fold (Figure 2). Moreover, qPCR analysis revealed that the frequency of nifH was the highest in the rock samples and lowest in the sediment samples. The gravel-like sample was found to have at least 10 times more copies of bacterial-amoA (AOB), as compared to the rock and sediment samples (Figure 2). Due to the low frequency of $\mathrm{AOB}$ in $\mathrm{R}$ and $\mathrm{S}$ samples, we decided to investigate the archaeal-amoA (AOA) in those samples (Figure 2). Arch-amo $A$ was detected at $10^{5}$ to $10^{6}$ copies per gram, indicating the occurrence of ammonia oxidation in those samples. Almost 10-times more copies of the Arch-amoA was detected in the sediment samples, as compared to the rock and gravel-like samples. It is noteworthy that the nifH gene was detected at $10^{5}$ to $10^{6}$-fold in comparison with $\mathrm{AOB}$, which was detected at $10^{3}$ to $10^{4}$-fold copies of the gene per gram.
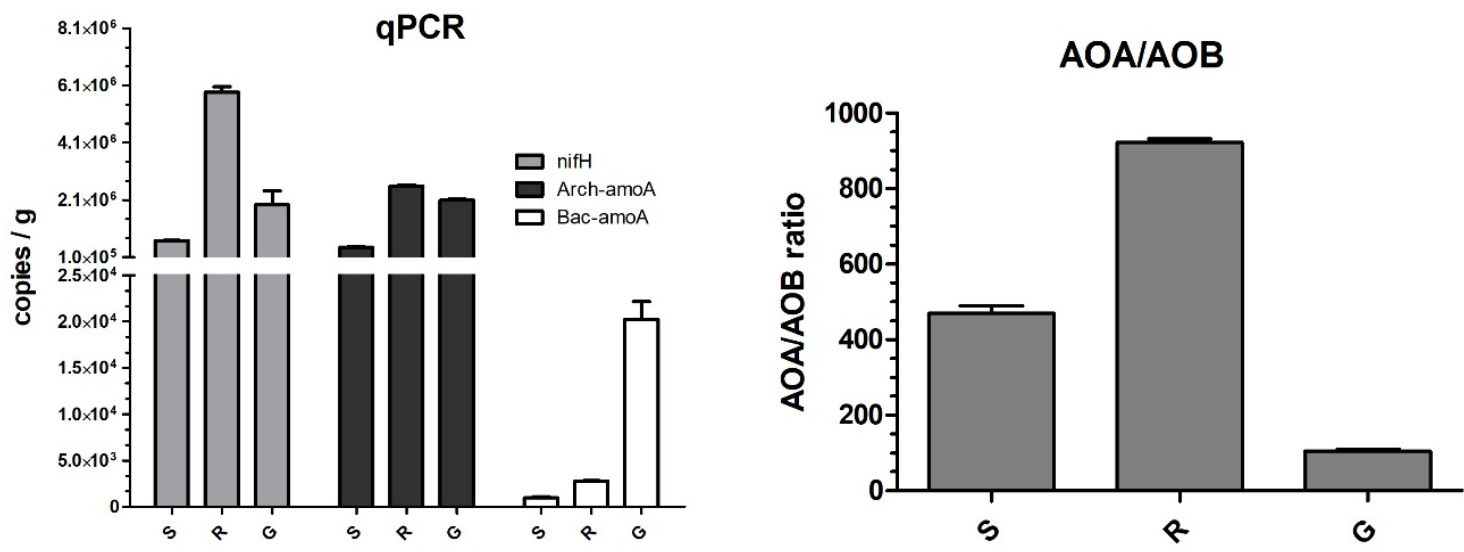

Figure 2. Quantitative PCR (qPCR) of genes associated with nitrogen fixation and ammonia oxidation and the archaeal and bacterial ammonia oxidation ratio (AOA/AOB). The bacterial nitrogen fixing gene (nifH), archaeal (AOA), and bacterial (AOB) ammonia-oxidizing genes in sediment (S), gravel-like $(\mathrm{G})$, and rock sample $(\mathrm{R})$. Assays were performed in triplicate $(n=3)$, bars represent standard deviation.

The AOA/AOB ratio showed a dominance of AOA over AOB (Figure 2), at approximately 100-, 500- and 900-times in G, S, and R samples, respectively, indicating a considerable difference among the samples.

\subsection{EDX and Nitrogen Analysis}

We performed an EDX analysis in order to identify traces of elements in our samples. Among the identified elements described in Table 2, sulfur was detected in only one of the samples, while iron was a predominant component in all samples. The presence of iron ranged from $5 \%$ (sediment) to $17 \%$ (rock), explaining the reddish color of the samples. Silicon was present at nearly $15 \%$ in all samples, indicating a layer of arenite in the limestone rock. A small fraction of rock and gravel-like samples was dissolved with hydrochloride acid, following the observation of some resistant grains in the sediment sample after dissolution, probably due to the presence of silicon dioxide. 
Table 2. Energy-dispersive X-ray spectroscopy analysis of cave sediment (S), gravel-like (G), and rock (R) samples. Values in \% followed by the standard deviation.

\begin{tabular}{cccccccccc}
\hline Samples & $\mathbf{C}$ & $\mathbf{O}$ & $\mathbf{F e}$ & $\mathbf{M g}$ & $\mathbf{A l}$ & $\mathbf{S i}$ & $\mathbf{K}$ & $\mathbf{C a}$ & $\mathbf{S}$ \\
\hline $\mathbf{S}$ & $5.04 \pm 4.56$ & $62.95 \pm 4.84$ & $4.96 \pm 1.54$ & 0.00 & $11.52 \pm 2.8$ & $14.98 \pm 4.59$ & 0.00 & $0.54 \pm 0.42$ & 0.00 \\
$\mathbf{G}$ & 11.55 & $51.28 \pm 1.41$ & $12.40 \pm 1.82$ & $0.66 \pm 0.42$ & 8.56 & $14.62 \pm 4.31$ & $0.07 \pm 0.06$ & $0.43 \pm 0.29$ & $0.44 \pm 0.35$ \\
$\mathbf{R}$ & $6.78 \pm 2.16$ & 50.471 .82 & $16.91 \pm 1.88$ & 0.00 & $9.24 \pm 3.4$ & $15.90 \pm 2.91$ & 0.00 & $0.71 \pm 0.14$ & 0.00 \\
\hline
\end{tabular}

The rock sample was found to have higher content of ammonia and nitrate, while the sediment sample showed higher nitrogen content (Table 3). Ammonia, nitrate, and total nitrogen ranged from 42 to $75 \mathrm{mg} / \mathrm{kg}$, 38 to $59 \mathrm{mg} / \mathrm{kg}$, and 2.60 to $2.87 \mathrm{~g} / \mathrm{kg}$, respectively. The organic matter content was also evaluated. However, the results obtained were below the minimum detectable value $(5 \mathrm{~g} / \mathrm{L})$ in all samples. The rock sample was found to have higher $\mathrm{pH}$ as compared to the other samples, which were close to neutral ( $\mathrm{pH} 7$ ), with the gravel-like sample being slightly alkaline and the sediment sample being slightly acidic (Table 3 ).

Table 3. Total nitrogen, ammonia, nitrate (Values in $\mathrm{g} / \mathrm{kg}$ ), and $\mathrm{pH}$ of cave sediment (S), gravel-like $(\mathrm{G})$, and rock (R) samples.

\begin{tabular}{ccccc}
\hline Samples & Nitrogen & Ammonia & Nitrate & pH \\
\hline S & 2.87 & 0.042 & 0.046 & 6.4 \\
R & 2.83 & 0.075 & 0.059 & 8.9 \\
G & 2.60 & 0.067 & 0.038 & 7.6 \\
\hline
\end{tabular}

\section{Discussion}

The Brazilian caves, especially those in the Northeast located in the tropical zone [4-6], are scarcely explored in terms of their microbial diversity, with only a few existing microbiological studies to shed light on the microbial inhabitants in that region. We decided to work in the São Desidério area because the region is a biodiversity hotspot [28] inhabited by unknown microbial communities. The Buraco da Sopradeira was especially interesting to study due to the distinct reddish color of its rocks and different sediment granulometry (Figure S1). Predominance of the Chromatiales (also known as purple sulfur bacteria), detected in oxic and aphotic sections of the cave, was initially unexpected due to the popular association of this PSB with photosynthesis and anaerobic environments [11], and by the non-detection of sulfur in the EDX analysis. Moreover, previous studies in caves showed that the photosynthetic PSB are the dominant bacteria in photic zones of caves [16], rather than the aphotic zone, as detected in our study. Moreover, one of the dominant PSB identified in this cave chamber was a member of a relatively new family of facultative anaerobic PSB, Woeceiaceae [29], that was not included in one of the database used. However, this brings forth an important question: How do such bacteria enter the cave ecosystem and dominate the bacterial community?

It may be speculated that microorganisms, such as the PSB, entered the cave ecosystem many years prior. Considering that most of the limestone caves in Northeastern Brazil were either associated with flooding and/ or with a river during ancient times [30], it is plausible that a transport of microorganisms, such as PSB, including photosynthetic ones, (as previously detected, Cyanobacteria), took place near the cave river area [4]. Moreover, the indication of runoff, airflow, or a flowing river, albeit for a short duration since cave formation, can explain the higher presence and accumulation of Bacillaceae in the floor, as they were detected in greater abundance in the sediment samples. Interestingly, these Bacilli were found to increase with a decrease in $\mathrm{pH}$, indicating that they might demonstrate some unknown metabolic activities. Moreover, the alkaline $\mathrm{pH}$ and the total absence of light in the sampling site supports the idea of a predominance of non-photosynthetic PSB. However, the failure to isolate PSB and the notion that photosynthetic activity is an ancient feature in PSB [31] encouraged us to further investigate whether the PSB in the Sopradeira cave could perform photosynthesis, had lost the genes needed for photosynthesis, or produced inactive 
photosynthetic-related proteins. As we did not expect the dominance of PSB, we were unable to try techniques to isolate them, including an anaerobic collection. Moreover, due to the restrictions in sampling, only one chamber was analyzed and the result may not be representative to the whole Sopradeira cave environment. Furthermore, the reduced sampling (approximately $100 \mathrm{~g}$ ) that we were authorized restrict the geochemical analysis feasible to be performed. The lack of geochemical information restricts our understanding on PSB metabolism and how it thrives in cave ecosystem.

Among the possible activities that PSB may be related to in the cave are carbon fixation [16] and sulfur metabolism. However, the absence of light and detectable sulfur in the sampling site decreased the possibility of these two metabolic activities performed by the PSB. Nonetheless, non-photosynthetic carbon fixation may not be altogether disregarded. Nitrogen metabolism is known for more than 60 years in PSB [32], and a recent study showed the presence of the nifH gene in several members of Chromatiales [13]. This corroborates our finding by qPCR and $16 \mathrm{~S}$ rDNA sequencing that nifH was present at a high frequency. The high-intensity bands observed on nifH-DGGE analysis (Figure S4) made with the same volume of PCR product, confirming the presence of the nifH in high copy numbers in the rock sample. Indeed, the level of potential nitrogen fixating bacteria observed in the present study was 100-times higher than a previous study from our group in another limestone cave [4] and supported the idea of PSB related with nitrogenase activity in the studied chamber of Sopradeira cave. The surprisingly high level of nifH was unexpected because of the amount of energy spent to fix one $\mathrm{N}_{2}$ molecule [33]. However, it is plausible to assume that part of the nifH detected in the samples may not form an active nitrogenase, since the presence of nifH does not guarantee expression and full function of this multigenic enzyme [34]. However, it is a strong indication regarding a potential activity, albeit the nitrogenase enzyme is known to be involved in other reactions [35]. Furthermore, the presence of nifH gene does not guarantee nitrogen fixing activity, and these bacteria may have other genes related with biogeochemical cycles, indicating that despite the presence of nitrogenase, these bacteria may also be associated with other biochemical reactions.

Curiously, the total levels of nitrogen, ammonia, and nitrate determined in our study were similar to our findings from a previous study in another cave, where 100-times less nifH copies per gram were detected [4], which may be a relatively constant number for tropical caves. It is interesting to note that the nifH and ammonia (nitrogen fixation product) values were higher in the sample with more PSB abundancy (rock) and higher pH. The rock sample in DGGE (Figure S4) presented a high number of bands in spite of using different primers for nifH amplification, and the sequenced bands matched with Chromatiales in the NCBI database (Text S1). These findings, the Good's coverage value, rarefaction curve (Figure S3), and the abundance of bacteria support our assumption that PSB in Sopradeira cave is associated with nitrogenase enzyme, especially considering the fact that no other bacterial group detected in the study had the potential to present such high copy numbers of the nifH gene. It is interesting to note that, in another iron-rich cave sample (from ferromanganese deposit) [10], nitrogencycle-related bacteria and Bacilli from different families were detected. In the present study, the microorganisms transported to the cave appear to have adapted to perform a similar or the same function.

Initially, we envisaged that PSB in the cave samples were ammonia-oxidizers. However, the difference between $\mathrm{AOB}$ and nifH, evident from our qPCR results, suggests a greater presence of potential nitrogen-fixing bacteria than $\mathrm{AOB}$ in the samples, in addition to the presence of multiple copies of these genes per genome [36]. The predominance of PSB inside the cave may be attributed to the nifH gene due the high copy numbers. However, a small fraction of the AOB present, appeared to be PSB, as identified by $16 \mathrm{~S}$ rDNA sequencing, albeit by low-confidence identification. These bacteria were identified as Nitrosococcus, a known ammonia-oxidizer [36]. The observation that AOB were only a small percentage of the total microbial population inhabiting the cave prompted us to investigate if AOA were the dominant ammonia -oxidizing bacteria in the samples. Interestingly, AOA was found to be approximately 10- (Sediment) to 100-times (rock and gravel-like) more as compared to the findings of our previous study in another Brazilian cave [4]. Thereafter, the AOB population seemed to present 
the same level leading to an $\mathrm{AOA} / \mathrm{AOB}$ ratio, which was higher than that observed in the other study, especially considering that $\mathrm{AOB}$ genomes have one to three copies of the amoA gene, while known the archaeal genome only has one copy [37].

\section{Conclusions}

The predominance of PSB brings many questions, but the limited funding, especially during the current Brazilian science crisis [38], narrowed our possibilities to better characterize the environment and investigate a broad of potential PSB activities in caves and remnants of their life in surface. The predominance of PSB observed in the present study is one of many examples of diverse and unexpected microbial colonization $[6,8,10]$, making the caves an exciting place to study unique microbial communities. Nevertheless, in most countries, the legislation neglects microbial communities in caves. The Brazilian legislation, for example, classified caves according to a rank scheme of protection mainly related with geology and zoology. A recent study proposed alternative methods [39], but failed to mention microorganisms. NGS techniques became affordable in recent years, enabling its application in diversity analysis and facilitating the inclusion of evaluating the microbial community in cave (and many other) legislation around the world. This will not only encourage the study of unique microbial communities, like the one in the present study, but also open potential avenues for discovery of new biotechnologically interesting biomolecules [40] that represent an important genetic patrimony. To the best of our knowledge, our group is the first to demonstrate the predominance of purple sulfur bacteria in dark zones of cave samples. Our study suggests that PSB in the Sopradeira cave participate in the nitrogen cycle. The study also improves the knowledge of PSB in oxic, aphotic, and non-sulfurous environments. However, more studies need to be conducted to investigate the PSB activity in such caves. Due to the unexpected predominance of these bacteria and our focus on the biotechnological potential in the bacterial isolation technique, we were unable to isolate PSB from our samples. However, future work may be directed towards the isolation of such bacteria from this cave and investigate if PSB in aphotic zones still have photosynthetic potential. Nevertheless, the analyzed chamber in the Sopradeira cave presents an opportunity for studying ammonia-oxidizing archaea and a diverse microbial community of PSB in the aphotic environment to improve the understanding of the Chromatiales class in different ecosystems.

Supplementary Materials: The following are available online at http://www.mdpi.com/2076-2607/7/2/29/s1, Figure S1: Images of the size of sediment (A), gravel-like (B) samples, and a piece of the rock sample; Figure S2: Spectrographs generated in the EDX analysis of Sopradeira cave samples; Figure S3: Rarefaction curves of rock, sediment and gravel-like samples from Sopradeira cave; Figure S4: Denaturing Gradient Gel electrophoresis (DGGE) of nifH gene community in the rock (R), sediment (S), and gravel-like (G) samples; Table S1: List of genus and family identify in the 16S rDNA sequencing of sediment (S), gravel-like $(\mathrm{G})$, and rock (R) samples collected in Sopradeira cave. Text S1: Denaturing Gel Gradient Electrophoresis of nifH gene.

Author Contributions: Conceptualization, E.L.S.M., J.C.T.D., and R.P.R.; methodology, E.L.S.M., E.G., R.P.R., J.C.T.D., A.B.d.C.e.S., and S.R.d.M.; formal analysis, E.L.S.M., A.B.d.C.e.S., and S.R.d.M.; investigation, E.L.S.M., E.G., A.B.d.C.e.S., and S.R.d.M.; resources, E.L.S.M., R.P.R., J.C.T.D., and E.G.; data curation, J.C.T.D., E.G., and R.P.R.; writing—original draft preparation, E.L.S.M.; writing—review and editing, E.L.S.M., J.C.T.D., R.P.R., S.R.M., and A.B.d.C.e.S.; supervision, R.P.R.; project administration, E.L.S.M., R.P.R.; funding acquisition, R.P.R.

Funding: This research was funded by National Council for Scientific and Technological Development (CNPq), grant number 482721/2012-0. E.L.S.M. was funded by Coordenação de Aperfeicoamento de Pessoal de Nível Superior (CAPES). A.B.C.S was funded by Fundação de Amparo à Pesquisa do Estado da Bahia (FAPESB).

Acknowledgments: We would like to thank Centro de Microscopia Eletrônica from State University of Santa Cruz (CME/UESC) for the technical support of EDX analysis, and organization of 32 Congresso Brasileiro de Espeleologia for the help in the sampling expedition.

Conflicts of Interest: The authors declare no conflict of interest. The funders had no role in the design of the study; in the collection, analyses, or interpretation of data; in the writing of the manuscript, or in the decision to publish the results. 


\section{References}

1. Poulson, T.L.; White, W.B. The cave environment. Science 1969, 165, 971-981. [CrossRef] [PubMed]

2. Northup, D.E.; Lavoie, K.H. Geomicrobiology of caves: A review. Geomicrobiol. J. 2001, 18, 199-222.

3. Barton, H.A.; Taylor, N.M.; Kreate, M.P.; Springer, A.C.; Oehrle, S.A.; Bertog, J.L. The impact of host rock geochemistry on bacterial community structure in oligotrophic cave environments. Int. J. Speleol. 2007, 36, 93-104. [CrossRef]

4. de Lima Silva Marques, E.; Gross, E.; Teixeira Dias, J.C.; Priminho Pirovani, C.; Passos Rezende, R. Ammonia oxidation $(a m o A)$ and nitrogen fixation $(n i f H)$ genes along metasandstone and limestone caves of Brazil. Geomicrobiol. J. 2018, 1-10. [CrossRef]

5. de Paula, C.C.P.; Montoya, Q.V.; Rodrigues, A.; Bichuette, M.E.; Seleghim, M.H.R. Terrestrial filamentous fungi from Gruta do Catão (São Desidério, Bahia, Northeastern Brazil) show high levels of cellulose degradation. J. Cave Karst Stud. 2016, 78, 208-217. [CrossRef]

6. Barton, H.A.; Giarrizzo, J.G.; Suarez, P.; Robertson, C.E.; Broering, M.J.; Banks, E.D.; Vaishampayan, P.A.; Venkateswaran, K. Microbial diversity in a Venezuelan orthoquartzite cave is dominated by the Chloroflexi (Class Ktedonobacterales) and Thaumarchaeota Group I.1c. Front. Microbiol. 2014, 5, 1-14. [CrossRef]

7. Taylor, E.L.S.; Resende Stoianoff, M.A.; Lopes Ferreira, R. Mycological study for a management plan of a neotropical show cave (Brazil). Int. J. Speleol. 2013, 42, 267-277. [CrossRef]

8. Parker, C.W.; Auler, A.S.; Barton, M.D.; Sasowsky, I.D.; Senko, J.M.; Barton, H.A. Fe(III) reducing microorganisms from iron ore caves demonstrate fermentative Fe(III) reduction and promote cave formation. Geomicrobiol. J. 2018, 35, 311-322. [CrossRef]

9. Chen, Y.; Wu, L.; Boden, R.; Hillebrand, A.; Kumaresan, D.; Moussard, H.; Baciu, M.; Lu, Y.; Colin Murrell, J. Life without light: Microbial diversity and evidence of sulfur- and ammonium-based chemolithotrophy in Movile Cave. ISME J. 2009, 3, 1093-1104. [CrossRef] [PubMed]

10. Northup, D.E.; Barns, S.M.; Yu, L.E.; Spilde, M.N.; Schelble, R.T.; Dano, K.E.; Crossey, L.J.; Connolly, C. a; Boston, P.J.; Natvig, D.O.; et al. Diverse microbial communities inhabiting ferromanganese deposits in Lechuguilla and Spider Caves. Environ. Microbiol. 2003, 5, 1071-1086. [CrossRef]

11. Madigan, M.T.; Martinko, J.M.; Bender, K.S.; Buckley, D.H.; Stahl, D.A. Brock Biology of Microorganisms; Pearson: Boston, MA, USA, 2015.

12. Lavy, A.; Keren, R.; Yu, K.; Thomas, B.C.; Alvarez-Cohen, L.; Banfield, J.F.; Ilan, M. A novel Chromatiales bacterium is a potential sulfide oxidizer in multiple orders of marine sponges. Environ. Microbiol. 2018, 20, 800-814. [CrossRef]

13. Tourova, T.P.; Spiridonova, E.M.; Berg, I.A.; Slobodova, N.V.; Boulygina, E.S.; Sorokin, D.Y. Phylogeny and evolution of the family Ectothiorhodospiraceae based on comparison of $16 \mathrm{~S}$ rRNA, cbbL and nifH gene sequences. Int. J. Syst. Evol. Microbiol. 2007, 57, 2387-2398. [CrossRef]

14. El Sheikh, A.F.; Poret-Peterson, A.T.; Klotz, M.G. Characterization of two new genes, amoR and amoD, in the amo operon of the marine ammonia oxidizer Nitrosococcus oceani ATCC 19707. Appl. Environ. Microbiol. 2008, 74, 312-318. [CrossRef] [PubMed]

15. Ahn, A.-C.; Meier-Kolthoff, J.P.; Overmars, L.; Richter, M.; Woyke, T.; Sorokin, D.Y.; Muyzer, G. Genomic diversity within the haloalkaliphilic genus Thioalkalivibrio. PLoS ONE 2017, 12, e0173517. [CrossRef] [PubMed]

16. Herbert, R.A.; Ranchou-Peyruse, A.; Duran, R.; Guyoneaud, R.; Schwabe, S. Characterization of purple sulfur bacteria from the South Andros Black Hole cave system: Highlights taxonomic problems for ecological studies among the genera Allochromatium and Thiocapsa. Environ. Microbiol. 2005, 7, 1260-1268. [CrossRef] [PubMed]

17. Porca, E.; Jurado, V.; Žgur-Bertok, D.; Saiz-Jimenez, C.; Pašić, L. Comparative analysis of yellow microbial communities growing on the walls of geographically distinct caves indicates a common core of microorganisms involved in their formation. FEMS Microbiol. Ecol. 2012, 81, 255-266. [CrossRef]

18. Marques, E.L.S.; Dias, J.C.T.; Silva, G.S.; Pirovani, C.P.; Rezende, R.P. Organic matter enrichment affects archaea community in limestone cave sediments. J. Cave Karst Stud. 2017, 79, 95-99. [CrossRef]

19. Marques, E.L.S.; Dias, J.C.T.; Silva, G.S.; Pirovani, C.P.; Rezende, R.P. Effect of organic matter enrichment on the fungal community in limestone cave sediments. Genet. Mol. Res. 2016, 15, gmr8611. [CrossRef]

20. Ribeiro, A.C.; Guimarães, P.T.G.; Alvarez, V.V.H. Recomendações para o uso de Corretivos e Fertilizantes em Minas Gerais, 5th ed.; Ribeiro, A.C., Guimarães, P.T.G., Eds.; CFSEMG: Viçosa, Brazil, 1999. 
21. Wang, Y.; Qian, P.-Y. Conservative fragments in bacterial $16 \mathrm{~S}$ rRNA genes and primer design for $16 \mathrm{~S}$ ribosomal DNA amplicons in metagenomic studies. PLoS ONE 2009, 4, e7401. [CrossRef] [PubMed]

22. Caporaso, J.G.; Lauber, C.L.; Walters, W.A.; Berg-Lyons, D.; Huntley, J.; Fierer, N.; Owens, S.M.; Betley, J.; Fraser, L.; Bauer, M.; et al. Ultra-high-throughput microbial community analysis on the Illumina HiSeq and MiSeq platforms. ISME J. 2012, 6, 1621-1624. [CrossRef] [PubMed]

23. Gohl, D.M.; Vangay, P.; Garbe, J.; MacLean, A.; Hauge, A.; Becker, A.; Gould, T.J.; Clayton, J.B.; Johnson, T.J.; Hunter, R.; et al. Systematic improvement of amplicon marker gene methods for increased accuracy in microbiome studies. Nat. Biotechnol. 2016, 34, 942-949. [CrossRef] [PubMed]

24. Wright, E.S.; Yilmaz, L.S.; Noguera, D.R. DECIPHER, a search-based approach to chimera identification for 16S rRNA sequences. Appl. Environ. Microbiol. 2012, 78, 717-725. [CrossRef] [PubMed]

25. Cole, J.R.; Wang, Q.; Fish, J.A.; Chai, B.; McGarrell, D.M.; Sun, Y.; Brown, C.T.; Porras-Alfaro, A.; Kuske, C.R.; Tiedje, J.M. Ribosomal Database Project: Data and tools for high throughput rRNA analysis. Nucleic Acids Res. 2014, 42, D633-D642. [CrossRef] [PubMed]

26. Yoon, S.-H.; Ha, S.-M.; Kwon, S.; Lim, J.; Kim, Y.; Seo, H.; Chun, J. Introducing EzBioCloud: A taxonomically united database of $16 \mathrm{~S}$ rRNA gene sequences and whole-genome assemblies. Int. J. Syst. Evol. Microbiol. 2017, 67, 1613-1617. [CrossRef] [PubMed]

27. Mao, Y.; Yannarell, A.C.; Mackie, R.I. Changes in N-transforming archaea and bacteria in soil during the establishment of bioenergy crops. PLoS ONE 2011, 6, e24750. [CrossRef]

28. Fernandes, C.S.; Batalha, M.A.; Bichuette, M.E. Does the cave environment reduce functional diversity? PLoS ONE 2016, 11, e0151958. [CrossRef]

29. Chen, G.-J.; Wang, Z.-J.; Du, Z.-J.; Zhao, J.-X. Woeseia oceani gen. nov., sp. nov., a chemoheterotrophic member of the order Chromatiales, and proposal of Woeseiaceae fam. nov. Int. J. Syst. Evol. Microbiol. 2016, 66, 107-112. [CrossRef]

30. Laureano, F.V.; Karmann, I.; Granger, D.E.; Auler, A.S.; Almeida, R.P.; Cruz, F.W.; Strícks, N.M.; Novello, V.F. Two million years of river and cave aggradation in NE Brazil: Implications for speleogenesis and landscape evolution. Geomorphology 2016, 273, 63-77. [CrossRef]

31. Imhoff, J.F.; Rahn, T.; Künzel, S.; Neulinger, S.C. Photosynthesis Is widely distributed among Proteobacteria as demonstrated by the phylogeny of PufLM reaction center proteins. Front. Microbiol. 2018, 8. [CrossRef]

32. Lindstrom, E.S.; Tove, S.R.; Wilson, P.W. Nitrogen fixation by the green and purple sulfur bacteria. Science 1950, 112, 197-198. [CrossRef]

33. Lee, C.C.; Ribbe, M.W.; Hu, Y. Cleaving the N,N Triple Bond: The transformation of dinitrogen to ammonia by nitrogenases. In The Metal-Driven Biogeochemistry of Gaseous Compounds in the Environment; Springer: Dordrecht, The Netherlands, 2014; pp. 147-176.

34. Dos Santos, P.C.; Fang, Z.; Mason, S.W.; Setubal, J.C.; Dixon, R. Distribution of nitrogen fixation and nitrogenase-like sequences amongst microbial genomes. BMC Genom. 2012, 13, 162. [CrossRef] [PubMed]

35. Rasche, M.E.; Seefeldt, L.C. Reduction of thiocyanate, cyanate, and carbon disulfide by nitrogenase: Kinetic characterization and EPR spectroscopic analysis. Biochemistry 1997, 36, 8574-8585. [CrossRef] [PubMed]

36. Norton, J.M.; Alzerreca, J.J.; Suwa, Y.; Klotz, M.G. Diversity of ammonia monooxygenase operon in autotrophic ammonia-oxidizing bacteria. Arch. Microbiol. 2002, 177, 139-149. [CrossRef] [PubMed]

37. Trias, R.; García-Lledó, A.; Sánchez, N.; López-Jurado, J.L.; Hallin, S.; Bañeras, L. Abundance and composition of epiphytic bacterial and archaeal ammonia oxidizers of marine red and brown macroalgae. Appl. Environ. Microbiol. 2012, 78, 318-325. [CrossRef]

38. Barbuy, B. Crisis in Brazil. Science 2018, 361, 1293. [CrossRef] [PubMed]

39. Jaffé, R.; Prous, X.; Zampaulo, R.; Giannini, T.C.; Imperatriz-Fonseca, V.L.; Maurity, C.; Oliveira, G.; Brandi, I.V.; Siqueira, J.O. Reconciling mining with the conservation of cave biodiversity: A quantitative baseline to help establish conservation priorities. PLoS ONE 2016, 11, e0168348. [CrossRef] [PubMed]

40. Gabriel, C.R.; Northup, D.E. Cave microbiomes: A novel resource for drug discovery. In Cave Microbiomes; Springer: Berlin, Germany, 2013; Volume 1, pp. 85-108, ISBN 978-1-4614-5205-8.

(C) 2019 by the authors. Licensee MDPI, Basel, Switzerland. This article is an open access article distributed under the terms and conditions of the Creative Commons Attribution (CC BY) license (http:// creativecommons.org/licenses/by/4.0/). 